\title{
Internet-based surveys and urban design education: A community outreach graduate project in Redding, CA
}

\author{
Vicente del Rio ${ }^{a}$, and Daniel Levi ${ }^{b}$ \\ ${ }^{a}$ City and Regional Planning Department, California Polytechnic State University, \\ San Luis Obispo, CA 93407, USA. \\ ${ }^{b}$ Psychology and Child Development Department, California Polytechnic State University, \\ San Luis Obispo, CA 93407, USA.
}

\begin{abstract}
This paper is a contribution to the discussion on how to incorporate community participation into the urban design process within a pedagogical context. It is based on an outreach project by a class in the city planning graduate program at California Polytechnic State University, San Luis Obispo. The project included an Internet survey to gather community input for a contentious riverfront site in Redding, CA. The responses permitted a study of perceptions, attitudes and expectations about the city and the project area, and an examination of design alternatives. The Internet survey provided 864 responses and generated a rich amount of information that was utilized in the programming and selection of design concepts for the project. The site's proprietors, the community and the media were in full support of the final project, which prompted the city council to appoint a special committee to oversee the advancement of specific policies and recommendations for the area's future development. The effectiveness of the method of public input and the successful project process suggest important pedagogical and professional implications.
\end{abstract}

Keywords: urban design education; web-based surveys; community participation; riverfront development; Redding, CA.

\section{Introduction}

The main goal of this paper is to contribute to the discussion on how to incorporate community participation through a web-based survey into form-giving and urban design within a pedagogical context. ${ }^{1}$ Our discussion is based on a community outreach project developed by a class in the city planning graduate program at the California State Polytechnic University, San Luis Obispo (Cal Poly) USA. The effectiveness of the method utilized to obtain public input and the success of the resulting project suggest important pedagogical and professional implications.

Community participation is a fundamental tool in all phases of the design process from analysis to visioning to design development to implementation. The participatory strategies and methods to be used vary with the scale and type of projects, the demographics of the population and the resources and time available. For university projects, some questions need to be addressed as well as their pedagogical implications. First, is it possible to educate students about community participation if they do not engage in it in real-life situations? How can we collect information from the community inexpensively, quickly, and in a useful manner? And last but not least, in the case of design studios, what type of public input can be useful to inform design, and how to transform this information into design concepts?

In this paper, we discuss a student project that incorporated an Internet survey as an effective means to gather community input for an urban design proposal. Probing for perceptions, attitudes and expectations about the city and project area, the survey contributed immensely 
to the vision, the program and the concepts that were the base for the final design. The successful methodology and the wide acceptance of the final project by the community suggest some important pedagogical and professional implications for urban design.

\section{Participation and Community Design in the United States}

The existing literature describes the disruption of the technocratic planning paradigm and the surge of a more socially conscious planning practice in the US starting in the 1960s as a result of the civil rights movements and disturbances, and the work of leading academic and political activists, such as Paul Davidoff and his 'advocacy planning' (Comerio 1984; Hoch, Dalton \& So, 2000; Sanoff, 1990, 2000). By the mid-1960s, the federal government was demanding that its social, housing and urban renewal programs include community participation. Planning processes incorporated public hearings and opened up participation for communities affected by the plans, leaving behind authoritarian models. More effective communication channels and wider participatory models would follow leading to stronger consensus building to make sure that all stakeholders could participate from the beginning of the decision-making processes.

At first, community design was born as a response to this new paradigm and from the notion that technical knowledge alone is not enough to solve problems affecting communities (Sanoff, 2000). Representing the addition of moral and political contents to professional practice, community design became a strong planning concept in the United States (Comerio, 1984; Sanoff, 2000). It implies not only working for a community but also with that community - a plan or project that is developed through a participatory decision-making process. Some people, like Appleyard (1982), consider community design as a form of urban design.

The Architectural Renewal Committee in New York's Harlem was the first community design center in the United States, organized in 1963 to help fight the project for an express highway in Upper Manhattan (Comerio, 1984). Soon other advocacy groups and community design centers were started across the United States, most of them by universities, the American Institute of Architects and NGOs. Schuman (1991) notes that one of the most significant and still in action today started at Pratt University, Brooklyn in 1970. Bachelor and Lewis (1985) describe the work of the American Institute of Architects' Regional/ URBAN DESIGN Assistance Teams (known as R/ UDATs) and how they got started in 1967 by a request from Rapid City's Chamber of Commerce for assistance in solving some of the city's urban problems.

In general, these centers relied on pro bono work from professionals, faculty and students, resources from the federal government (community development block grants) and donations (Comerio, 1984; Schuman, 1991; Sanoff, 2000). Schuman (1991) notes that although advocacy and community design suffered from the withdrawal of funds during the Republican administrations, several of them are still active. Many seem to be much less idealistic and more practice oriented - not surprisingly to ensure their own self-preservation within the academic structure.

In order to guarantee community access to the planning process, there is a complex set of national, state and local laws and regulations that determine how and when public input and community participation must occur. Planning's legal framework guarantees public participation and mandates that all information regarding a plan or project be open to the public through the whole planning process. Planning became more transparent to citizens and community groups who became more powerful in the United States, and particularly in California where this paper's context is set. The National Environmental Act (1969) and the California Environmental Quality Act (1970) are classic examples of legislation that established environmental impact review systems, which mandate considerable public input and participation. In the case of California, the state requires its counties and cities to have general (for a county or city) and specific plans (complementary to the general plan and for definite geographical areas); both have their formatting and content well defined and must include public participation processes (Fulton, 1999). ${ }^{2}$ The system also includes district plans and other planning instruments, such as zoning ordinances, design guidelines and review boards, that establish different levels of public input and participation.

In the case of California, opening the planning system to participation comes also at the cost of excesses, such as the so-called ballot planning: 
a curious form of planning in which a certain number of signatures may start a public referendum toward approving a project that otherwise would not be permitted according to an existing general plan or zoning legislation. This legal right of all California citizens definitely makes planning a political act (Fulton, 1999). In the city of San Luis Obispo, for instance, as a result of the advocacy work by a local community group, a special ballot was held in 2006 in which citizens reverted a city council's decision toward allowing a new shopping center to be built on existing farmland. As a response, the developer himself started another referendum and got the project approved at the county level! Fulton (1999) claims that planning in California works well when there is a wide variety of active community groups involved from the beginning, and when their forces balance out in the end.

Two curious and typical facts in North American planning should be noted here. First, consensus among stakeholders is essential to prevent long litigations and increasing costs in planning implementation. Second, building a consensus is part of the political scene in a representative democracy where citizens express their opinion, but decisions end up in the hands of their representatives committees or elected representatives - who in theory follow the consensus or majority opinion to avoid longer processes and litigation. As noted by Fulton (1999), in California, planning is really about politics and about getting the majority of votes in the local legislatures.

The public character of the planning profession is certainly a strong reason behind the existence of nearly 100 planning and urban studies program in the United States, 75 of which have their degrees accredited by the Planning Accreditation Board, according to the Association of Collegiate Schools of Planning. ${ }^{3}$ In 2000, more than 70 per cent of the planning professionals contributing to the American Planning Association worked for some kind of public agency (Hoch, Dalton and So, 2000). In general, students are attracted to planning programs because of their willingness to serve the public and their preoccupation with contemporary themes, such as global warming, sustainability, alternative transportation and place making. Moreover, thanks to the new 'theories' of new urbanism and smart growth, the planning profession is experiencing a return to more design-oriented approaches, and many students are welcoming such an interest and the urban design studios (Forsyth, 2004). As both new urbanism and smart growth advocate 'design charrettes' (intensive workshops with stakeholders) for master planning and urban design (Porterfield and Hall, 2001; Walters and Brown, 2004), community participation is an ongoing preoccupation for the profession and planning programs, which include courses such as community design methods, collaborative planning and planning for and with multiple publics.

\section{Community Outreach at Cal Poly and the Project}

Pedagogies that simulate the 'real world' and 'real problems' are commonly adopted in planning and design studios that try to emulate professional practice in order to educate students to deal with 'real-life situations' (Salama, 1995; Dutton, 2001). The common belief is that there is no substitute for the experience gained by a student that is engaged in 'learn-by-doing', particularly in a studio environment. This is especially important in planning education which, given its very nature, is supposed to make students very aware of their political, social and ethical responsibilities toward the communities they work for.

Several planning schools in the United States adopt such pedagogies, particularly in studios. This is true at Cal Poly whose motto includes the 'learn-by-doing' philosophy and hands-on experience where students can learn from real-life situations and from exposure to 'industry' - that is, to firms and the professional context. The City and Regional Planning Department (CRP), located within the College of Architectural and Environmental Design, reflects this philosophy in its mission and curriculum, which has a heavy studio component both at undergraduate and graduate levels. ${ }^{4}$ Relying on its mission and on the planning profession's ideal of social responsibility, the CRP department encourages community outreach work, particularly at the more advanced planning and urban design studios when students are mature enough to engage in a real project. Traditionally, faculty members seek real projects and clients - a community, a county or local government, or even a planning/design firm - for their studios, which results in a contract that specifies the project's terms and expected products. At the core of CRP's curriculum are the community design and community planning studios where students develop their projects 
and follow participatory process with their clients and the community as much as possible. The pedagogies follow a socially conscious paradigm and what we might call an 'action-research' approach based on the understanding of the characteristics, needs and behaviors of the communities (Salama 1995; Sanoff, 1977, 1990). In promoting ethical and social engagement in the studios, students are trained at identifying human and social needs, assessing the built and natural environment and making proposals that involve the communities; they are trained to be both a professional that solves a problem and a professional that facilitates the resolution of a problem. The CRP department is proud of having a long history of clients and community outreach projects, many of which are winners of awards from the American Planning Association.

Cal Poly's academic year of three 10-week quarters imposes a clear difficulty to studio courses both at the undergraduate and graduate levels. Project development is fast and very intense, requiring a lot of dedication from students and faculty, particularly when real clients are involved. Projects are finished and presented to the client by the end of the tenth week of classes, and final reports are delivered in the following week (exams' week) or, in the case of class projects, are compiled and edited by one or two class representatives sometimes for extra credit. At the graduate level, difficulties arise by the fact that the Master of City and Regional Planning is a professional program where the majority of students do not possess a planning or a design background..$^{5}$ Thus, developing a design-oriented graduate studio is always a challenge.

\section{The Project}

The project that we discuss here was brought to the college and the CRP Department by R2L Architects of San Luis Obispo who represented a family owning a 12-hectar underutilized parcel in Redding, North California. Enjoying a prime location on the western bank of the Sacramento River, the parcel represented a unique redevelopment opportunity and could anchor the city's revitalization efforts and re-establish the synergy between the city and its river. The proprietors had no money to hire the architects for this first phase of visioning and conceptual design, which in turn would be important to attract investors and the support of the city officials. CRP's graduate Planning Project Lab (CRP 553) took the challenge in the winter quarter of 2005, hoping to contribute to the process and play a major role in this important project. The class was initially composed of 19 graduate students (second year, MCRP), none with design backgrounds and facing their first design studio. ${ }^{6}$ Eventually, one undergraduate senior (BSCRP) was encouraged to take the class as an elective, so that he could contribute with his 'expertise' in urban design and computer programs. ${ }^{7}$

The work was developed in 10 weeks, and project development included site visits, eventual visits by the architects and the clients and an original Internet-based method for community participation. In the following sections, we will discuss the project development, its successful results and the impacts on Redding.

\section{The site}

The City of Redding has a population of around 85000 people and it is located in the north end of the Sacramento Valley, CA, 150 miles north of Sacramento, the state capital. Although the Sacramento River runs through the city and there are popular ski resorts and mountain destinations nearby, Redding has no specific attraction and its downtown suffers from the typical growth pattern of most US cities. The population lives spread out in suburbs, and the majority of shopping and a limited degree of socialization happen in shopping malls at the periphery of the city.

In the 1970s, the city performed a major revitalization effort and built a shopping center by covering up four of the original downtown blocks and privatizing the streets. This effort not only failed but also generated several negative impacts along its immediate surroundings. In the late 1990s, city efforts turned toward the Sacramento River, Redding's most important single resource, which was expected to play a vital part in the city's revitalization. The city invested in the riverfront by building nature trails and strengthening the existing convention center, and by working together with the powerful local McConnell Foundation in building the Turtle Bay nature museum and a botanical garden across the river. To link them, the foundation decided to have a bridge that could help Redding have a strong iconic image, and hired Santiago Calatrava for 

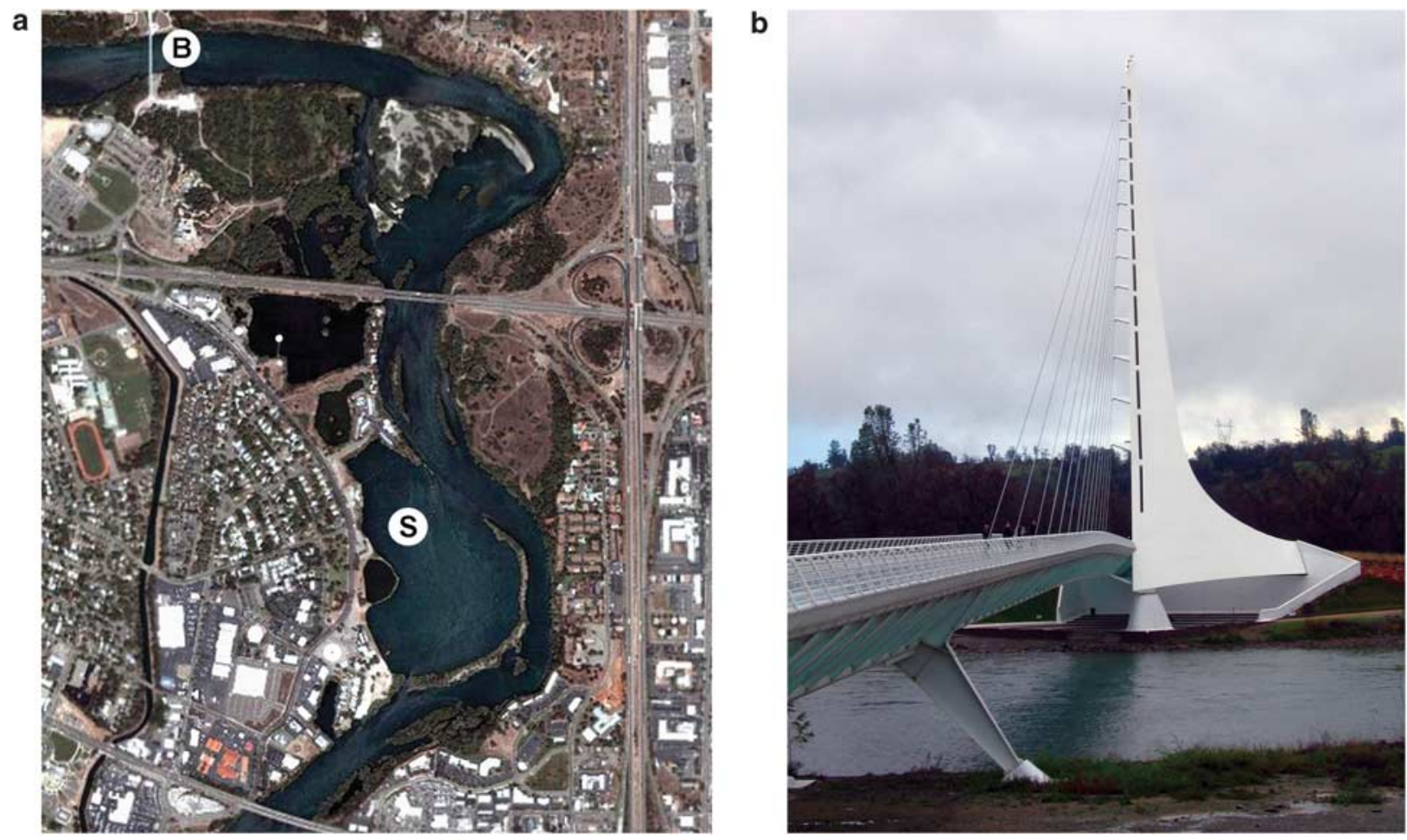

Figure 1: (a) The aerial photo shows the project area (S) limited by highways on the north and south edges, Park Marina Drive to the west and the Sacramento River to the east. In the north of the area, the convention center and the Sundial Bridge (B). (photo from the Google Earth). (b) The Sundial Bridge, designed by Santiago Calatrava.

the job. Typical of the famous Spanish architect, the Sundial Bridge is an elegant tensile structure hanging from a single column laying on one of the riverbanks, where a small plaza holds a sundial. Although it quickly became a city attraction, because it is located very close to the highway and to Redding's downtown, drivers make a detour to see the bridge but quickly return to the highway and their destinations.

The project site consisted of approximately 12 hectares along the west bank of the Sacramento River just south of Turtle Bay museum and the Sundial Bridge (Figure 1). Just $5 \mathrm{~min}$ away from the downtown it enjoys excellent accessibility to the rest of the city and the region since it is limited on the north and south by major roads, and on the west by the Park Marina Drive, a street connecting the county government center in the south to the highway at site's northern edge. The site is mostly surrounded by residences except in the southwest corner where there are offices and a couple of underutilized big 'box' retailers including a small movie theater. There are two large water intakes in the site that resulted from digging out soil and rocks for the construction of the famous Shasta Dam, which controls flood- ing along the river. Buildings and uses along the project site were mostly outdated, badly maintained and underutilized with the exception of a group of single family residences, an apartment complex, a small motel, a trailer park and a couple of retailers. An existing small park on the west side of Park Marina Drive also belonged to the same proprietors and was incorporated into the project.

The site was very contentious because of a series of past disagreements and mistrust between the family who owned the area, the City of Redding and the McConnell Foundation (whose long-term lease on parts of the property was about to expire) had gridlocked negotiations on how and what type of development should occur. In addition, the existing city specific plan for the area was outdated, relied mostly on office uses and dedicated a large part of the property to parking. Thus, one of the major goals for this class and the project they developed was to help overcome this political gridlock and make stakeholders come back to the table to collaborate on the fate of the site.

By re-envisioning development alternatives for the site, the class was hoping to help the disparate parties come together and contribute to the 
creation of something truly special for the community. Moreover, the property owners expected the project to acknowledge their incredibly scenic and valuable property, to respond to city policies and community expectations and to provide them with acceptable profits.

\section{The process}

Project development was designed into four phases: (a) site analysis; (b) literature review and case studies; (c) community workshops and visioning; and (d) design development. The biggest constraint the class had in developing this process was that Redding is located at an 8-hour car drive from San Luis Obispo, making field visits and any kind of community involvement extremely difficult to say the least.

During the first phase, the class traveled to Redding for an extended weekend and met with city officials and various stakeholders. Existing data were collected, the site and surrounding areas were studied and a pilot survey was conducted when 27 residents and visitors at various locations were interviewed on their perceptions and expectations about the city and the project area. During this initial visit, we met with one of the editors of the local newspaper - the Record Searchlight - and received support for our work. At the end of this first phase, the class had gathered a good understanding of the site and city dynamics, as well as of community needs and market demands.

The second phase, a review of urban design literature and of case studies of similar projects, provided the class with an awareness of applicable concepts and design typologies, preparing them for visioning, the next step in the process. The third phase would have involved community workshops and visioning, but as noted before, the location of the site did not allow the class to rely on traditional community participation methods. So, an alternative methodology was devised to conduct a survey through the Internet using the newspaper to reach out to the community.

The newspaper was contacted and agreed to publish an article on waterfront revitalization and our work objective in which readers were encouraged to participate in the design process by responding to an Internet-based survey. ${ }^{8}$ The survey's main objective was to allow the community to share their opinions, and examine respondents' attitudes about the city and the project area, how they thought the area should be developed, what they thought the new design should entail and their visual preferences of design alternatives. ${ }^{9}$

Although most of the Internet survey contained fixed-format questions giving people constrained choices about development of the site, it also contained a few open-ended questions that did allow unconstrained, creative ideas from respondents. There were 25 questions grouped into several sections: 8 attitude ratings about development of the riverfront area, 4 sets of ratings about development options, an open-ended question asking what types of development people would like to see in the riverfront area, 9 visual preference ratings with scenes of retail development, parks and housing and 3 questions about the respondents' background.

The survey was conducted using the site 'surveymonkey.com', and it was available for 10 days, after which we closed it and tabulated and analyzed the results. We received 864 online responses as well as a few additional e-mails and letters sent directly to us. This was considered a very high rate of response and indicated a community that was truly interested in participating in the decision-making process about the future of the area and their city. They shared with us their perceptions about the site as it now exists, their preferences for its future design and other thoughts on how future developments should look like in the area.

\section{Survey results and design}

In the first section of the survey, a majority of survey respondents agreed that the Sacramento riverfront is one of Redding's most important assets, that it is currently underutilized, and that it should be a focal point of the community (Figure 2; Table 1). The public was looking for change in the project area. They disagreed that 'the Park Marina Drive area should remain in its current state', and agreed that the buildings currently there were 'no longer appropriate for the site'.

Table 2 shows the types of amenities and development that the public wanted at the site. The respondents wanted recreational facilities at the site, especially recreational activities for teenagers. Desired recreational features included sitting areas, nature preserve and trails and picnic areas. They were also interested in seeing dining 


\section{Untitled Page}

Please consider the following statements, and check all the answers that apply.

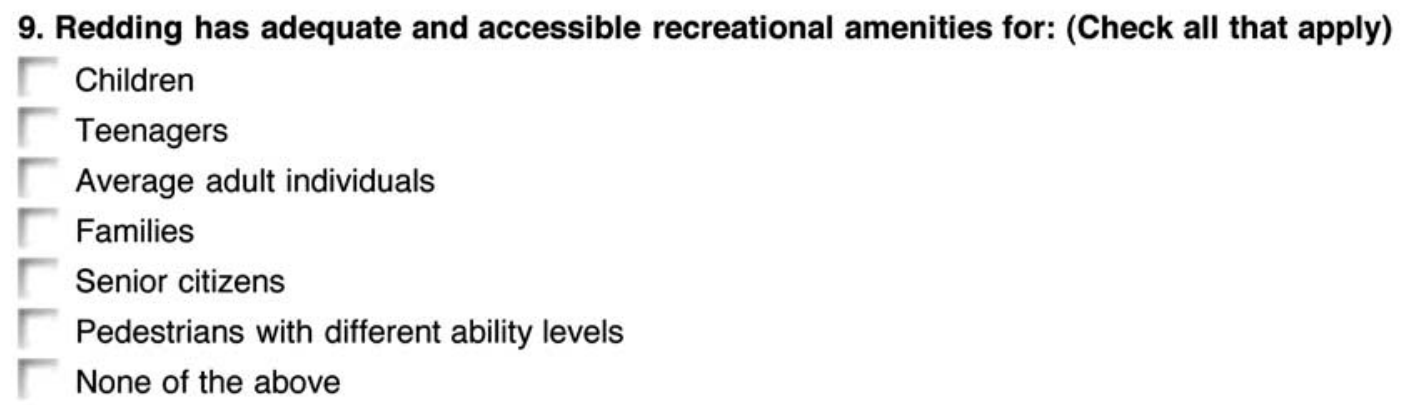

10. If a park were to be incorporated into a development in the Park Marina Drive area, what would you like to see there? (Check all that apply)

T Sitting Areas

$\Gamma$ Playground Equipment

$\Gamma$ Picnic and $\mathrm{BBQ}$ Areas

Nature Trail/Preserve

Athletic Facilities (such as tennis courts, basketball courts, soccer field)

$\Gamma$ Passive Activity Facilities (such as horseshoe pits, lawn bowling, shuffle board)

Recreation Room/Clubhouse

$\Gamma$ Other (please specify)

11. What types of development would you like to see along the Park Marina Drive area? (Check all that apply)

Entertainment Facilities (i.e. movie theater/music venue)

Nightlife Activities (i.e.dance club, bar)

THotels

$\Gamma$ Dining Establishments

$\Gamma$ Local Shops/Boutiques

T Big Box Stores

Various Types of Residential Units

Mixed-Use (combination of residential and retail/office in the same building)

$\Gamma$ Recreational Facilities

$\Gamma$ Other (please specify)

Figure 2: One of the survey's web pages showing the options that respondents could check out.

establishments and local shops/boutiques incorporated into the new development. There was little agreement on the architectural styles that respondents were most interested in seeing at the site, with historic and modern styles equally popular.

The open-ended question 'If development were to occur along the riverfront, what would you like 
Table 1: Attitude ratings about development of the riverfront area

\begin{tabular}{|c|c|c|c|c|}
\hline No. & Questions & $\%$ Agree & $\%$ Neutral & $\%$ Disagree \\
\hline 1 & $\begin{array}{l}\text { The Sacramento riverfront along the Park Marina Drive is one of the most important } \\
\text { assets of Redding. }\end{array}$ & 92 & 5 & 3 \\
\hline 2 & The Sacramento riverfront along park marina Drive is underutilized by the community. & 91 & 4 & 5 \\
\hline 3 & There are plenty of fun outdoors activities along the Sacramento River in Redding. & 25 & 13 & 62 \\
\hline 4 & Redding's riverfront should be a focal point for the community. & 89 & 6 & 5 \\
\hline 5 & The Park Marina Drive area should remain in its current state. It is fine the way it is. & 20 & 32 & 48 \\
\hline 6 & There is too much traffic along the Park Marina Drive. & 20 & 32 & 48 \\
\hline 7 & $\begin{array}{l}\text { The buildings that currently exist in the Park Marina Drive area are no longer } \\
\text { appropriate for the site. }\end{array}$ & 68 & 14 & 17 \\
\hline 8 & The Sundial Bridge has contributed positively to the character of the city. & 86 & 6 & 8 \\
\hline
\end{tabular}

Table 2: Amenity and development preferences

\begin{tabular}{|c|c|c|c|}
\hline \multicolumn{4}{|c|}{ Redding has adequate and accessible recreational amenities for the following groups: } \\
\hline $45 \%$ & Children & $34 \%$ & Senior citizens \\
\hline $44 \%$ & Average adults & $26 \%$ & Pedestrians with different ability levels \\
\hline $43 \%$ & Families & $20 \%$ & Teenagers \\
\hline \multicolumn{4}{|c|}{ If a park were to be incorporated into a development in the Park Marina Drive area, what would you like to see there? } \\
\hline $87 \%$ & Sitting areas & $40 \%$ & Passive activity facilities \\
\hline $81 \%$ & Nature trail/preserve & $19 \%$ & Recreation room/club house \\
\hline $71 \%$ & Picnic and barbecue areas & $16 \%$ & Athletic facilities \\
\hline $49 \%$ & Playground equipment & & \\
\hline \multicolumn{4}{|c|}{ What types of development would you like to see along the Park Marina Drive area? } \\
\hline $78 \%$ & Dining establishments & $24 \%$ & Mixed use (residential and retail/office) \\
\hline $65 \%$ & Local shops/boutiques & $15 \%$ & Hotels \\
\hline $55 \%$ & Recreational facilities & $7 \%$ & Residential units \\
\hline $33 \%$ & Entertainment facilities & $1 \%$ & Big box stores \\
\hline $33 \%$ & Nightlife activities & & \\
\hline \multicolumn{4}{|c|}{ What architectural style do you feel is the most appropriate along the Park Marina Drive? } \\
\hline $36 \%$ & Historic & $20 \%$ & Art deco \\
\hline $31 \%$ & Modern & $17 \%$ & Brick \\
\hline $24 \%$ & Lodge style & $16 \%$ & Spanish \\
\hline
\end{tabular}

to see there?' was included to allow the community members to voice their opinion in their own words. Of the total surveys completed, 739 of them had this answer filled out. The students did a content analysis and summarized the recommendations in Figure 3. Most answers mentioned recreational facilities or shopping, with walking areas, restaurants, shops and trails as other popular suggestions.

The survey included a section with a visual preference study, in which the respondents had to look at three groups of three photos depicting different design types for retail, housing and park settings (Figure 4). Although the photos were intended to represent general concepts, respondents were reacting to specific images, so the results present only a general sense of impressions. However, they provided the students with a good understanding of the type of built environment most appropriate for the area from the perspective of the community.

There was a strong preference for park setting images, a strong dislike of the single-family housing type images and a mixed response for the retail images. Greatest preference went for the images that showed an activity or setting adjacent to water, such as cafes and park benches. The strongest dislike centered on images with the most urban flavor, such as tall row houses and boxy strip malls. Although mixed use was preferred in other parts of the survey, the mixed-use image did not draw strong acceptance (Table 3).

The survey's final section had three background questions about gender, age and zip code of the respondents (Table 4). Although more women completed the survey than men, the 


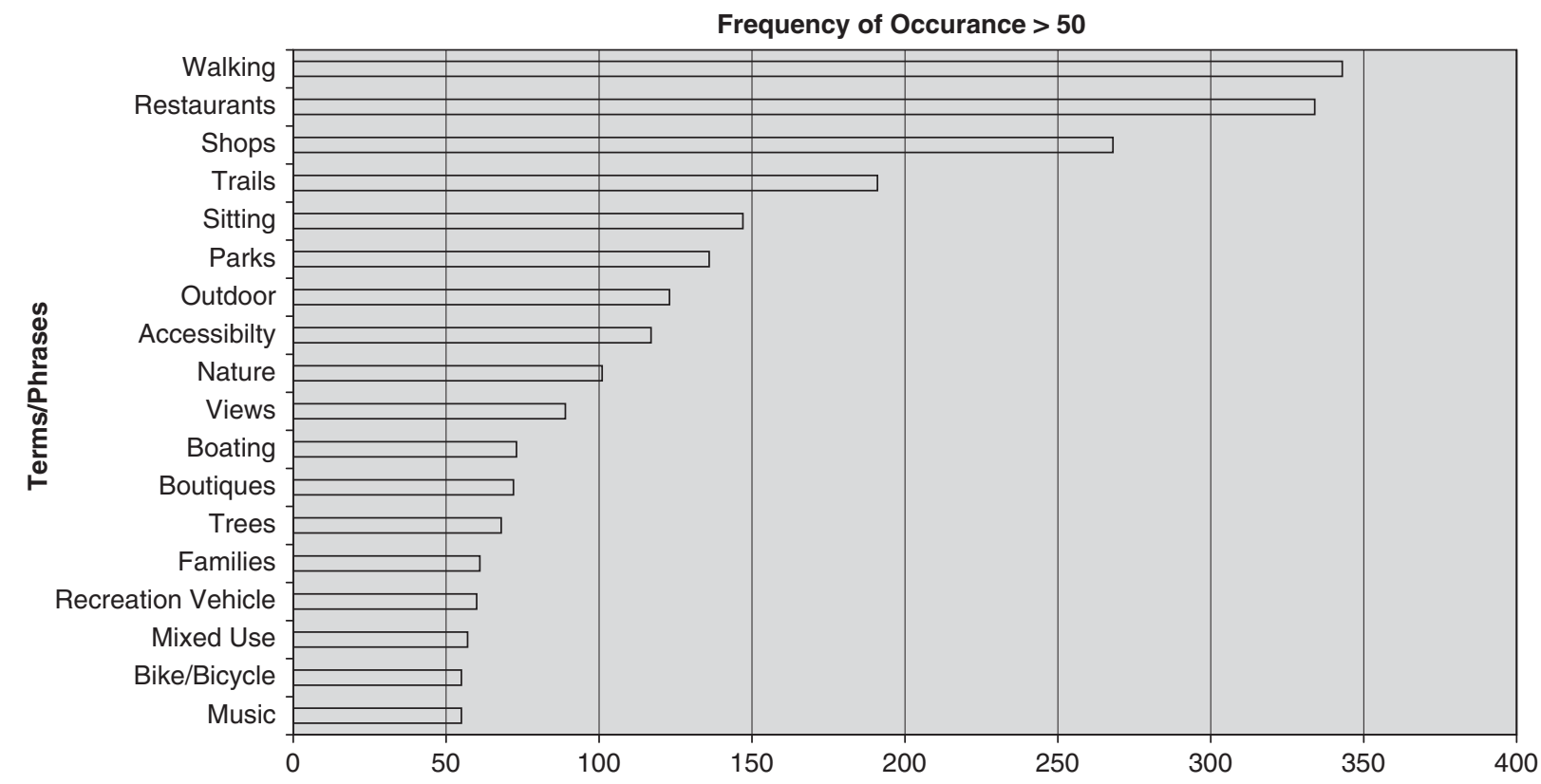

Figure 3: Content analysis - summarized recommendations.

distribution of respondents was not significantly different from the census data. The survey respondents were primarily between the age of 35-54 years, a distribution that differs from the census due to fewer respondents above 75 years. If the above 75-year group is combined with the 55-74-year group, then the survey distribution is not significantly different from the census. The respondents' distribution of zip codes in Redding was statistically similar to the census, and only about 10 of the respondents listed zip codes either outside of Redding or in post office boxes in Redding.

The survey results were written into an article format and published in the local newspaper to inform the community, and to keep their interest in the development of our class project. The survey not only helped the class to understand the community perception of the area, but it provided an incredibly rich array of information on what kind of planning and design elements would be probably most successful there. So the final part of the third phase consisted in translating all the information we already had, including the survey results into a vision, a set of goals and objectives, a series of design concepts and an urban design concept diagram. A lot of the design solutions came straight from the survey answers.

Finally, in the forth and last phase, an urban design plan was developed in which three major subareas were identified and where the development scenarios reflected the program that resulted from the survey and previous studies. These were complemented by calculations of how much square footage was needed for each building envelope, each use, and how much parking was made available. The final products were illustrative posters, a Powerpoint presentation and a final report that included all phases and the final design proposal, illustrated by a site plan, its photomontage onto the aerial photo, a series of drawings and computer mapping and renderings utilizing GIS, Autocad, SketchUp and Photoshop.

\section{The urban design solution}

Building upon all the information that was collected the student team developed a program, a vision, a set of goals, objectives, design concepts and the final concept plan. The vision reflects the community expectations for the area: The intent of the Park Marina Area Concept Plan is to revitalize Redding's riverfront and create a unique place that is a destination for both the community and visitors. Sustainability, vitality and social interaction will be facilitated by providing an array of compatible wateroriented recreational and cultural uses that are accessible to all segments of the community.

The project incorporated all of the natural beauty the site had and looked to emphasize all 


\section{Visual Preferences-Retail Developments}

These next questions are intended to get an overall understanding of your aesthetic preferences for future development in the Park Marina Drive area.

Photos are provided by: Elizabeth Fitzzaland, Vicente del Rio, and the Local Government Commission.

\section{Please take a minute to evaluate this image of a retail development that incorporates housing.}

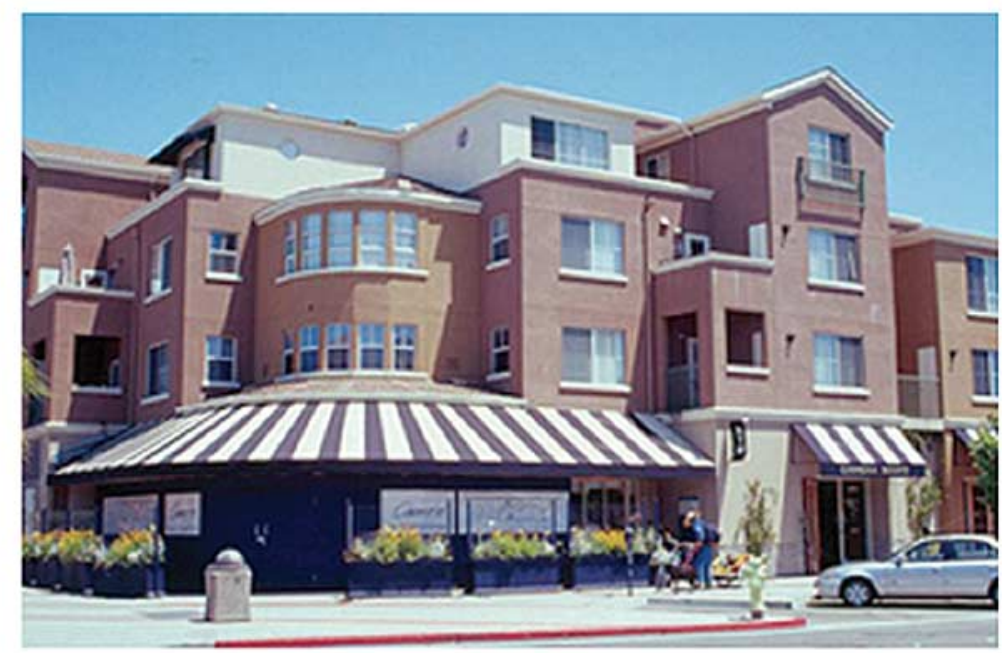

14. Please indicate how appropriate this development would be for the Park Marina Drive area.

$\checkmark$ Not at all appropriate

$\checkmark$ Somewhat appropriate

$\circlearrowleft$ Appropriate

$\checkmark$ Very appropriate

\section{$\ll$ Prev Next $\gg$}

Figure 4: One of the pages in the web survey showing one of the three mixed-use options that the respondents had to choose in the visual preference study.

of the potential it held for the future of the area and region (Figure 5, 6 and 7). Although the vast majority of the site (more than 50 per cent) was kept for open space, the project also provides ways for developers to create economic plans that will fit well in the community, which is one of the established goals of a truly mixed-use development.

Of the 27 acres in the Park Marina area, 18 acres will be dedicated to open space for various recreational uses. Open spaces are connected by pedestrian and bicycle trails, and to the existing trail systems to the north and south. They meander along the water's edge, the proposed boardwalks and piers, revealing picturesque views of the river.

New development on the site will include an outdoor amphitheater by the water's edge, a 12-screen theater complex, 145 residential units of different types and sizes, two hotels and a bed-andbreakfast, a marketplace with eateries, a permanent facility for a farmers market and seasonal craft fairs, an arts plaza and more than 1000 parking spaces in two new three-story parking structures and along the street. The Park Marina Drive would be turned from a simple thoroughfare 
Table 3: Summary of visual preference survey

\begin{tabular}{|c|c|c|c|c|c|}
\hline Image & Not at all appropriate & Somewhat appropriate & Appropriate & Very appropriate & Total \\
\hline \multirow[t]{2}{*}{ Mixed-use retail } & $45 \%$ & $34 \%$ & $13 \%$ & $8 \%$ & $100 \%$ \\
\hline & 380 & 281 & 110 & 67 & 838 \\
\hline \multirow[t]{2}{*}{ Box retail } & $85 \%$ & $11 \%$ & $3 \%$ & $1 \%$ & $100 \%$ \\
\hline & 716 & 93 & 21 & 8 & 838 \\
\hline \multirow[t]{2}{*}{ Riverfront café } & $9 \%$ & $21 \%$ & $22 \%$ & $48 \%$ & $100 \%$ \\
\hline & 74 & 173 & 184 & 408 & 839 \\
\hline \multirow[t]{2}{*}{ Active water park } & $9 \%$ & $21 \%$ & $26 \%$ & $39 \%$ & $100 \%$ \\
\hline & 78 & 213 & 214 & 329 & 834 \\
\hline \multirow[t]{2}{*}{ Tot lot } & $43 \%$ & $33 \%$ & $16 \%$ & $8 \%$ & $100 \%$ \\
\hline & 359 & 270 & 132 & 69 & 830 \\
\hline \multirow[t]{2}{*}{ Park benches } & $2 \%$ & $9 \%$ & $26 \%$ & $63 \%$ & $100 \%$ \\
\hline & 13 & 77 & 217 & 527 & 834 \\
\hline \multirow[t]{2}{*}{ 5-story apartments } & $84 \%$ & $10 \%$ & $4 \%$ & $2 \%$ & $100 \%$ \\
\hline & 703 & 80 & 35 & 13 & 831 \\
\hline \multirow[t]{2}{*}{ Craftsman bungalow } & $72 \%$ & $20 \%$ & $6 \%$ & $2 \%$ & $100 \%$ \\
\hline & 601 & 164 & 52 & 15 & 832 \\
\hline \multirow[t]{2}{*}{ two-story townhomes } & $49 \%$ & $30 \%$ & $15 \%$ & $6 \%$ & $100 \%$ \\
\hline & 402 & 251 & 127 & 47 & 827 \\
\hline
\end{tabular}

Numbers in italics represent the total hits of each answer.

Table 4: Background characteristics of survey respondents

\begin{tabular}{lcc}
\hline & Survey & Census \\
\hline Gender & & \\
Male & $43 \%$ & $48 \%$ \\
Female & $57 \%$ & $51 \%$ \\
Age (years) & & \\
$20-34$ & $17 \%$ & $27 \%$ \\
$35-54$ & $50 \%$ & $38 \%$ \\
$55-74$ & $30 \%$ & $24 \%$ \\
$75+$ & $1 \%$ & $10 \%$ \\
Zip code & & \\
96001 & $42 \%$ & $31 \%$ \\
96002 & $23 \%$ & $29 \%$ \\
\hline
\end{tabular}

to a tree-lined boulevard with a landscaped median, contributing to the pedestrian-friendly environment.

Reflecting most of the respondents' expectations as well as the site's context, the concept plan was divided into three subareas. The northern section includes housing and mixeduse development oriented toward the river. A sense of place is created through the integration of public plazas, seating areas, paths and greenways. The central section is predominantly reserved for open space and recreational uses, including a formal park with an old fashioned merry-go-round, a water feature sculpture, an artificial sand beach, a playground, barbecue pits, tables, seating and facilities, such as multipurpose kiosks (Figure 7). The southern section was destined to become an exciting, vibrant and pedestrian-friendly place with unique features, such as the marketplace, small shops and restaurants, two bedand-breakfasts, an outdoor amphitheater with a floating stage and a boat ramp.

Thus, just as the surveys showed us what the city needed and the community wanted, the Park Marina Area Concept Plan aims to offer a mix of uses and activities in a high-quality environment that integrates the riverfront into community life, creates a new destination in Redding, attracts tourists and helps revitalize the downtown.

\section{The Aftermath}

Newspaper coverage of the final design proposal preceded the class presentation of the project to the community in a public session held on a Saturday morning in the county's board of supervisor's chamber (Figure 8). ${ }^{10}$ On the presentation day, the newspaper published an article with a very positive evaluation of the project disclosing its support for the students' vision. The community responded positively to the proposal and approved it without restrictions. On the day after the presentation, the news headline was 'Student project enthralls - residents cheer ideas to recast Park Marina'. Evidently our clients were very happy with the results as they opened new 


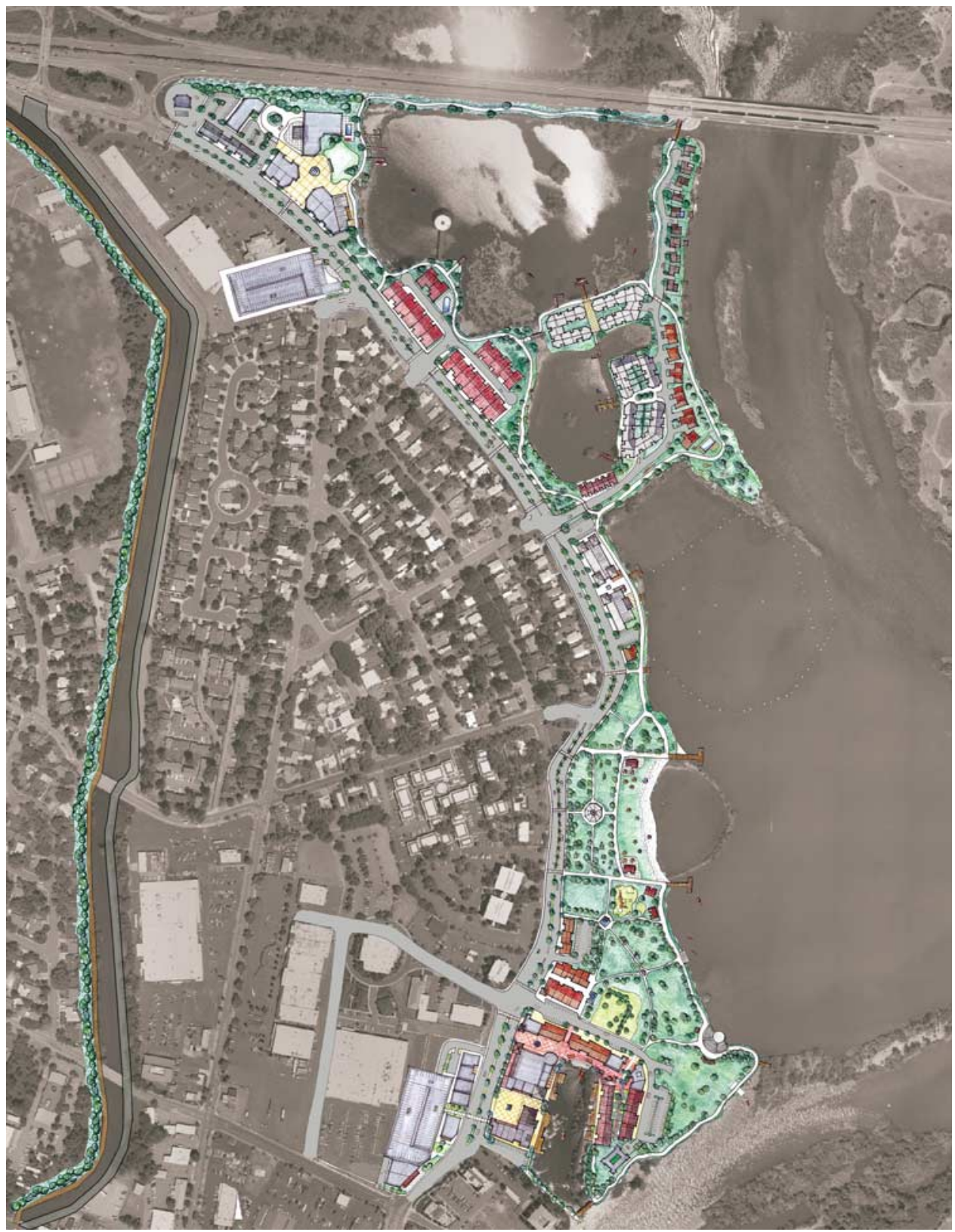

Figure 5: Illustrative site plan showing the insertion of the proposal in the actual site.

avenues for a sustainable and community-friendly development of their property.

Several articles in the local newspaper recognized the superiority of Cal Poly's plan over the existing specific plan for the riverfront area, particularly for providing a humanistic approach, more recreational and public uses, smarter land uses and much less land dedicated to parking. The process prompted the city council to appoint a community advisory committee to study the proposal, promote meetings with all stakeholders, develop recommendations and to study changes to the existing specific plan.

Pedagogically speaking, the project was very educational and showed the students not only the process of developing an urban design plan that included effective research methods, visioning and programming based on client and community inputs. Cal Poly's Park Marina Area Concept Plan received the 2006 Award of Merit from the Central Coast Session, California Chapter of the American Planning Association. 


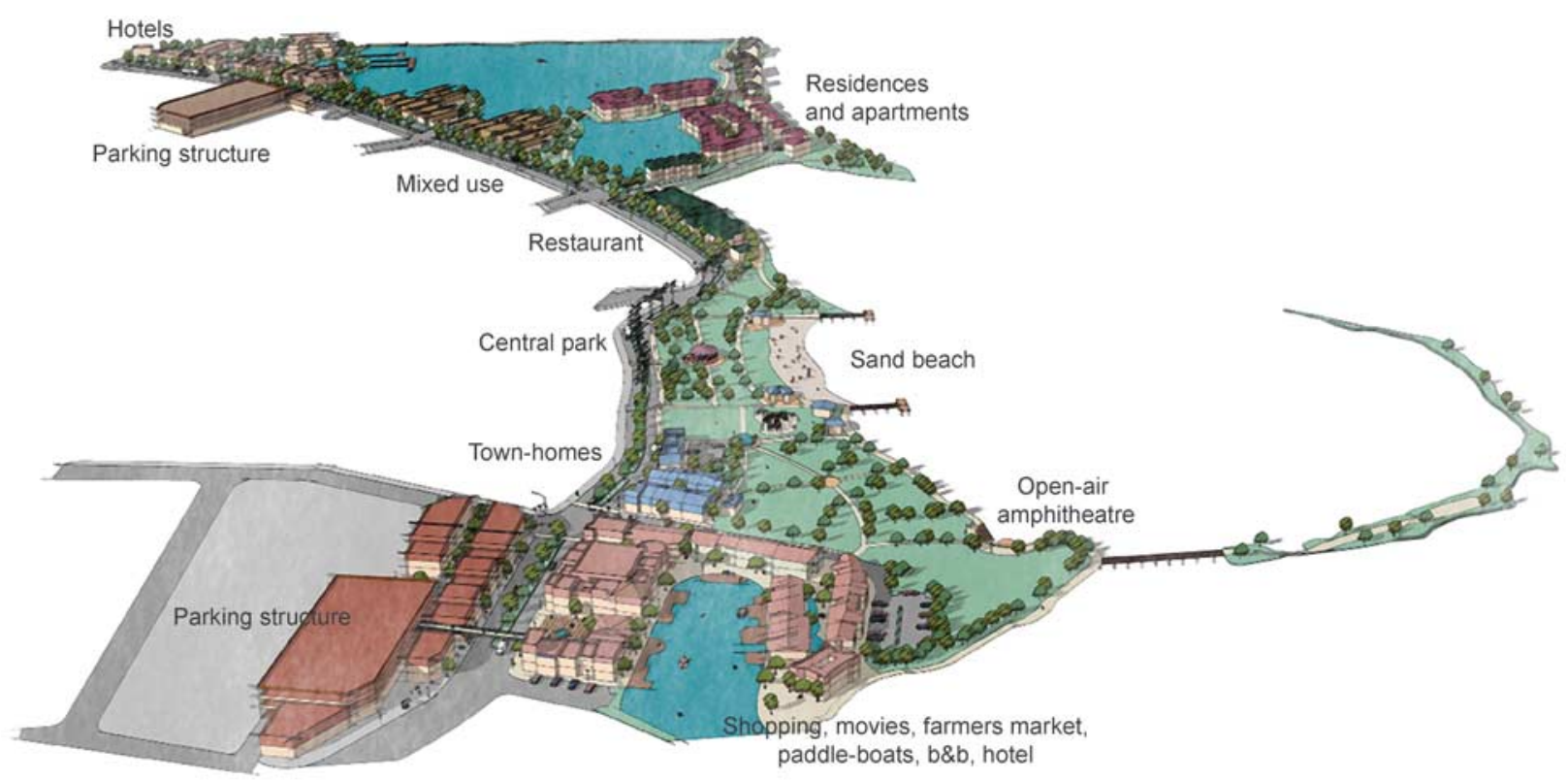

Figure 6: Computer rendering (SketchUp) showing a general bird's eye view of the project site looking the south.

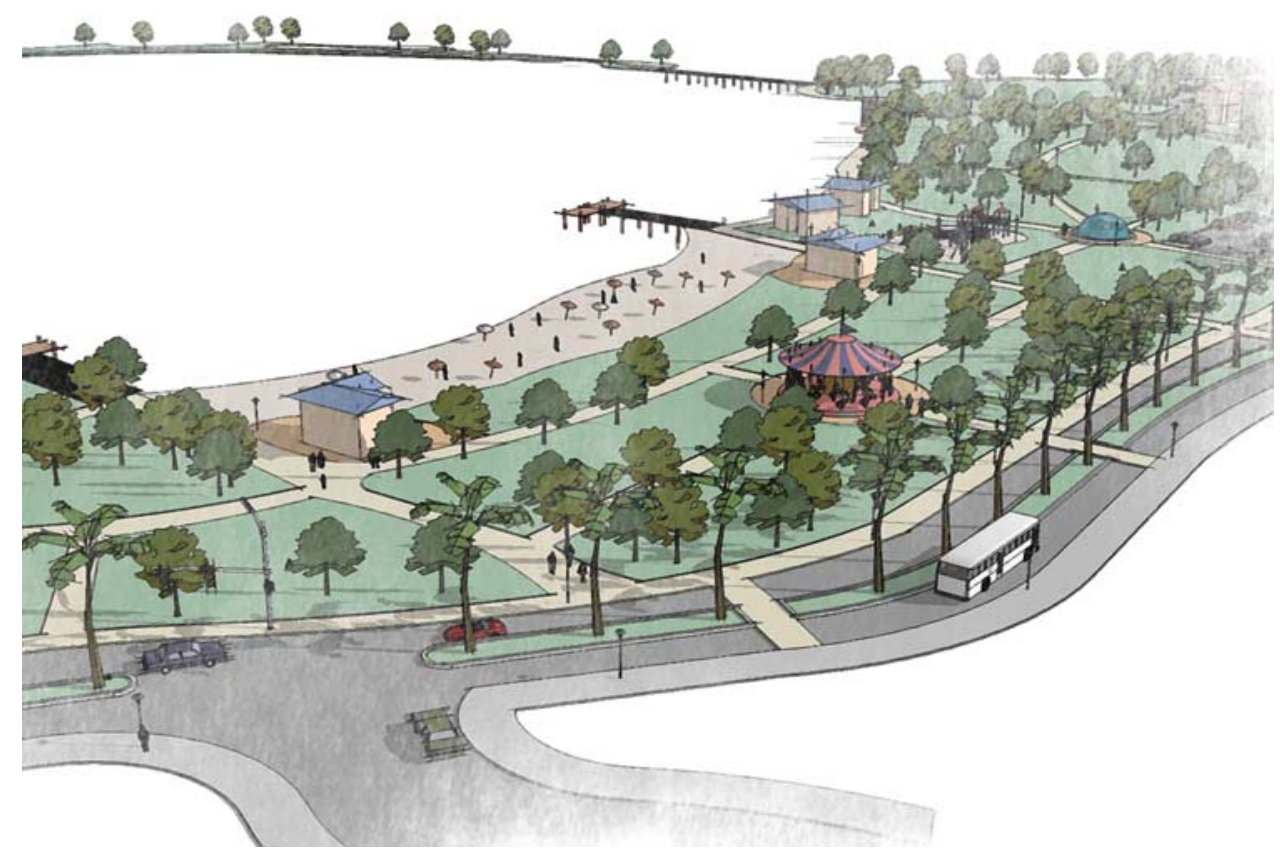

Figure 7: An image of the central section showing the park and the new boulevards. The artificial sand beach was based on the historical fact that was the city's population used to bath and recreate there in the past. The merry-go-round was suggested in one of the letters we received from a local resident who remembered that feature in the area when he/she was young.

\section{Conclusion}

The support of the local community, city government, the media and the proprietors showed that the class was successful with their proposal. This success would have been impossible without the design methodology utilized, and particularly the Internet-based survey. The survey proved to be a fundamental tool for public participation, allowing the class to build upon the community's expectations and to incorporate the public opinion into the program and design ideas. However, 


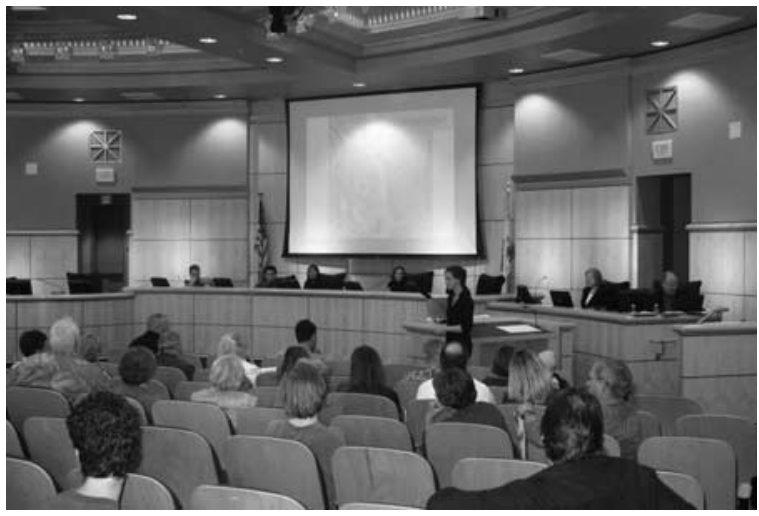

Figure 8: Students presenting the final proposal in a public session at the county board of supervisors' meeting hall.

there are several important considerations in using this approach to community participation.

It is important to make sure that the Internet survey gathers useful, realistic information. As noted above, in the first phase of the project and before developing the survey, the students conducted a site analysis and interviewed key participants and city officials besides conducting a pilot survey in the city. This helped the team to understand the place and the constraints and opportunities for the site; considerations that were used to construct the survey.

One of the values of using surveys as a community participation technique is to obtain a large sample that represents the community. It is important to collect background information on the survey participants and compare this information with the characteristics of the community. If the survey participants do not match the social characteristics, then the responses can be statistically adjusted. With the use of the Internet-based survey, the planning team was concerned about obtaining a representative sample of the community.

Two potential problems with this type of survey must be considered: access to the Internet and its increased use by younger community members. Although not everyone in Redding has Internet access, the public libraries provide the community access to computers and the web. When promoting the survey, availability at the libraries was communicated to the public. Another important issue to consider is over participation by younger residents, which was not a problem in the Redding survey. One reason for this is that the Internet survey was promoted through the newspaper, whose readers tend to be older community members. These two factors seemed to have canceled each other out in Redding.
Any real planning or urban design project must ensure that community participation happens in different levels and as widely as possible through different methods. One must be aware that Internetbased surveys have several drawbacks, particularly due to its very nature, as not all the population has access to a computer and are computer literate. However, if seen as one of the tools that can be utilized within a public participatory design framework, the method proved to be extremely successful not only for project information but also as an educational tool. Through this project, students learned how to obtain an understanding of community perceptions, expectations and values, and how to transform them into a design vision, contributing to a meaningful real-life development process.

\section{Notes}

1 This is an extended and revised version of a paper originally presented at the International Seminar on Urban Form in Ouro Preto, Brazil, 2007.

2 This format is set by the state. See State of California Governor's Office of Planning and Research at www. opr.ca.gov.

3 See Association of Collegiate Schools of Planning (2009). Guide to Undergraduate and Graduate Education in Urban and Regional Planning. 14th edn. ACSP. See also www.acsp.org.

4 See < http://www.caed.calpoly.edu/> and < $<$ http://planning. calpoly.edu/>

5 Most students hold bachelor's degree in Environmental and Urban Studies, Geography, History, Biology and so on. In some classes, there are one or two students with a background in landscape architecture and, more rarely, in architecture.

6 The class instructor was Vicente del Rio, and Daniel Levi was the consultant for environmental psychology and survey construction and analysis.

7 Cal Poly's undergraduate students take a graphic skills class and three urban design studios.

8 The article 'Seeking Redding's Future on the Riverfront' by Vicente del Rio and Sean Nicholas appeared in the Opinion section of the Record Searchlight on 6 February 2005.

9 The class used < surveymonkey.com> as the online resource to construct, administer and gather the survey results.

10 Redding's the Record Searchlight published an extensive and illustrated first-page article (local section) titled 'Designs shape riverfront - Students will unveil plan for Park Marina on Saturday' setting the stage for the public presentation. There were more than 100 members of the community in the presentation.

\section{References}

Appleyard, D. (1982) Three kinds of Urban design practice. In: M. Pittas and A. Farebee (eds.) Education for URBAN DESIGN. New York: The Institute for URBAN DESIGN. 
Bachelor, P. and Lewis, D. (eds.) (1985) URBAN DESIGN in Action, Student Publication, Vol. 29. Raleigh, NC: School of Design, North Carolina State University/American Institute of Architects.

Comerio, M. (1984) Community design: Idealism and entrepreneurship. Journal of Architecture and Planning Research 1: 227-243.

Hoch, C., Dalton, L. and So, F. (2000) Introduction: Planning for people and places. In: C. Hoch, L. Dalton and F. So (eds.) The Practice of Local Government, 3rd edn. Washington DC: International City-County Management Association/ American Planning Association.

Dutton, T. (ed.) (2001) Voices in Architectural Education: Cultural Politics and Pedagogy. New York: Bergin \& Gavey.

Forsyth, A. (2004) Responses to the graduate planning school study - The view from design. Journal of Planning Education and Research 24 No. 1: 23-27.

Fulton, W. (1999) Guide to California Planning, 2nd edn. Point Arenas, CA: Solano Press.
Porterfield, G. and Hall, K. (2001) Community by Design: New Urbanism for Suburbs and Small Communities. New York: McGraw Hill.

Salama, A. (1995) New Trends in Architectural Education. Raleigh, NC: Published by the author/Tailored Text \& Unlimited Publishing.

Sanoff, H. (1977) Methods of Architectural Programming. Stroudsburg, PA: Downden, Hutchison \& Ross.

Sanoff, H. (1990) Partipatory Design: Theory and Techniques. Raleigh, NC: Published by the author.

Sanoff, H. (2000) Community Participation Methods in Design and Planning. New York: John Wiley \& Sons.

Schuman, T. (1991) Forms of resistance: Politics, culture and architecture. In: T. Dutton (ed.) Voices in Architectural Education: Cultural Politics and Pedagogy. New York: Bergin \& Gavey.

Walters, D. and Brown, L. (2004) Design First: Design Based Planning for Communities. Oxford: Architecture Press. 